\title{
Proviral load does not discriminate patients with Human T-Cell Leukemia/Lymphoma (ATLL) from HTLV-1 carriers with a history of Strongyloidiasis
}

\author{
Giovanni López ${ }^{1 *}$, Elsa González², Daniel Clark, Michael Talledo, Carolina Alvarez', Kristien Verdonck,
} Angélica Terashima', Eduardo Gotuzzo'

From 15th International Conference on Human Retroviruses: HTLV and Related Viruses

Leuven and Gembloux, Belgium. 5-8 June 2011

\section{Background}

Studies evidences that high proviral loads (PVL) are crucial for the leukemogenesis in the development of ATLL. PVL seems to be stable for years in each individual, but varies substantially among subjects. Previous reports suggest that co-infection of HTLV-1 carriers with S. stercoralis may shorten ATLL onset, thus generating a hypothetical "intermediate state". We explored this hypothesis by comparing the PVL of ATLL patients and HTLV-1/Strongyloides co-infected individuals.

\section{Methods}

We determined PVL in three groups: (1) HTLV-1 asymptomatic carriers without a history of Strongyloidiasis $[\mathrm{AC}](\mathrm{n}=8)$; (2) virus carriers with previous episodes of Strongyloidiasis [SS] $(\mathrm{n}=8)$; and (3) patients with ATLL $[\mathrm{AT}](\mathrm{n}=8)$. History of Strongyloidiasis was defined by the patient's report and a positive result with a ELISA. Peripheral blood mononuclear cells (PBMC) were isolated to measure PVL by Sybr-Green quantitative PCR. PVL was expressed as HTLV-1 tax copy number $/ 10^{4}$ PBMC. Non-parametric tests were used for the statistical analysis.

\section{Results}

The PVL in AT was significantly higher than that in AC $[7375 \pm 4492 S D$ vs. $1698 \pm 106 \mathrm{SD}][\mathrm{p}=0.01]$. PVL was also higher in SS than in AC [4746 \pm 1712 SD vs.1698 $\pm 106 S D]$ $[\mathrm{p}=0.002]$. Interestingly, no differences were found between AT and SS $[7375 \pm 4492$ SD vs.4746 \pm 1712 SD] $[\mathrm{p}=0.16]$.

\section{Conclusion}

Our results support the hypothesis that HTLV-1/S. stercoralis co-infected subjects are at higher risk of developing ATLL as they seem to share with ATLL patients impaired immunological mechanisms to control virus propagation. Further studies are needed to fully characterize the co-infected condition.

\section{Author details}

${ }^{1}$ Instituto de Medicina Tropical "Alexander von Humboldt", Universidad Peruana Cayetano Heredia, Lima, 31, Perú. Facultad de Medicina Alberto Hurtado, Universidad Peruana Cayetano Heredia, Lima, 31, Perú.

${ }^{3}$ Laboratorios de Investigación y Desarrollo (LID), Facultad de Ciencias y

Filosofía, Universidad Peruana Cayetano Heredia, Lima, 31, Perú.

Published: 6 June 2011

\section{doi:10.1186/1742-4690-8-S1-A253}

Cite this article as: López et al:: Proviral load does not discriminate patients with Human T-Cell Leukemia/Lymphoma (ATLL) from HTLV-1 carriers with a history of Strongyloidiasis. Retrovirology 2011 8(Suppl 1): A253.

\footnotetext{
* Correspondence: gioloc2000@yahoo.com

${ }^{1}$ Instituto de Medicina Tropical "Alexander von Humboldt", Universidad

Peruana Cayetano Heredia, Lima, 31, Perú

Full list of author information is available at the end of the article
}

(c) 2011 López et al; licensee BioMed Central Ltd. This is an open access article distributed under the terms of the Creative Commons Attribution License (http://creativecommons.org/licenses/by/2.0), which permits unrestricted use, distribution, and reproduction in any medium, provided the original work is properly cited. 